\title{
Determinants of stunting and overweight among young children and adolescents in sub-Saharan Africa
}

Citation for published version (APA):

Keino, S., Plasqui, G., Ettyang, G., \& van den Borne, B. (2014). Determinants of stunting and overweight among young children and adolescents in sub-Saharan Africa. Food and Nutrition Bulletin, 35(2), 167178. https://doi.org/10.1177/156482651403500203

Document status and date:

Published: 01/01/2014

DOI:

10.1177/156482651403500203

Document Version:

Publisher's PDF, also known as Version of record

Document license:

Taverne

Please check the document version of this publication:

- A submitted manuscript is the version of the article upon submission and before peer-review. There can be important differences between the submitted version and the official published version of record.

People interested in the research are advised to contact the author for the final version of the publication, or visit the DOI to the publisher's website.

- The final author version and the galley proof are versions of the publication after peer review.

- The final published version features the final layout of the paper including the volume, issue and page numbers.

Link to publication

\footnotetext{
General rights rights.

- You may freely distribute the URL identifying the publication in the public portal. please follow below link for the End User Agreement:

www.umlib.nl/taverne-license

Take down policy

If you believe that this document breaches copyright please contact us at:

repository@maastrichtuniversity.nl

providing details and we will investigate your claim.
}

Copyright and moral rights for the publications made accessible in the public portal are retained by the authors and/or other copyright owners and it is a condition of accessing publications that users recognise and abide by the legal requirements associated with these

- Users may download and print one copy of any publication from the public portal for the purpose of private study or research.

- You may not further distribute the material or use it for any profit-making activity or commercial gain

If the publication is distributed under the terms of Article $25 \mathrm{fa}$ of the Dutch Copyright Act, indicated by the "Taverne" license above, 


\title{
Determinants of stunting and overweight among young children and adolescents in sub-Saharan Africa
}

\author{
Susan Keino, Guy Plasqui, Grace Ettyang, and Bart van den Borne
}

\begin{abstract}
Background. Stunting and overweight are nutritional problems affecting most of sub-Saharan Africa. The region now has the world's highest rate of stunting among children (43\%), while overweight and obesity are becoming a global epidemic, and Africa is not spared. The past two decades have seen a dramatic increase in obesity in sub-Saharan Africa.
\end{abstract}

Objective. The purpose of this systematic review is to explore the determinants of stunting and overweight in sub-Saharan Africa.

Methods. A literature search was conducted in PubMed using the key words stunting, overweight, obesity, Africa, sub-Saharan Africa, determinants, and prevalence. Limits were set to include articles published between 1990 and 2012. The systematic review resulted in 38 studies, and after selection based on title, content, and country of the study, 18 studies were eligible for this review. Data were analyzed by the chi-square test.

Results. The prevalence rates of stunting and overweight were dependent on socioeconomic, demographic, and environmental factors. Many studies indicate that male children and those living in a rural setting are more likely to be stunted, whereas overweight among children depends more on age, household composition, occupation of the mother, and the mother's body mass index. Stunting occurred together with overweight among both boys and girls from 1 to 5 years of age. Stunting was more prevalent among boys than among girls. Indicators of socioeconomic status, such as mother's education, mother's occupation, and household income, were some

Susan Keino, Guy Plasqui, and Bart van den Borne are affiliated with Maastricht University, Maastricht, Netherlands; Susan Keino and Grace Ettyang are affiliated with Moi University, Eldoret, Kenya.

Please direct queries to the corresponding author: Susan Keino, School of Public Health, Department of Epidemiology and Nutrition, Moi University, P.O. Box 4606, Eldoret, Kenya; e-mail: s.keino@maastrichtuniversity.nl or sansue_za@yahoo. com. of the determinants directly linked to stunting, whereas environmental factors, such as rural or urban setting and sanitation, influenced both stunting and overweight. Concurrent stunting and overweight is influenced by maternal and household factors, such as maternal height, age, and education, large household size, and lower socioeconomic status.

Conclusions. Although socioeconomic, demographic, and environmental factors were significant in determining stunting and overweight, other factors, such as nutrition and lifestyle, were important risk factors. Stunting in childhood is a risk factor that may result in overweight and obesity later in adolescence and adulthood, indicating the need to screen children below 1 year of age to identify stunting early in life. Promoting exclusive breastfeeding is reported to be important in preventing both stunting and overweight among children. More research is needed to explore the relationship between stunting and overweight and to explore policy guidelines to address the phenomenon.

Key words: Determinants, overweight, stunting, sub-Saharan Africa

\section{Introduction}

Chronic malnutrition is a persistent problem for young children in sub-Saharan Africa [1]. It is worth noting that malnutrition is a term that has often been used interchangeably with undernutrition in explaining nutritional problems, particularly in developing countries. A high percentage of malnourished children fail to reach the normal international standard of height for their age, i.e., they are stunted [1]. In the recent past, studies have shown different trends: increasing overnutrition in some countries and persistent undernutrition in other countries, particularly in sub-Saharan Africa [2]. According to Hoffman, the prevalence of obesity is increasing worldwide, including in some developing countries where the 
prevalence was previously very low [3]. The World Health Organization (WHO) defines overweight and obesity as conditions of abnormal or excessive fat accumulation [4]. A chronic positive energy balance normally precipitates the accumulation of excess adipose tissue. This positive energy balance is believed to be influenced by a number of environmental, socioeconomic, and physiological factors, such as high-fat diets and decreased physical activity. How these factors are manifested in developing countries is critical to the recent increase in obesity in countries undergoing transition with increasing urbanization [3].

WHO estimated that in 2005 there were more than 1 billion overweight adults globally, at least 300 million of them obese [5], and up to 20 million children under 5 years of age who were overweight [6]. There are no reliable statistics on obesity in Africa. However, more than one-third of African women and a quarter of African men are estimated to be overweight, and according to WHO these proportions will rise to $41 \%$ and $30 \%$, respectively, in the next 10 years [7]. On the other hand, the region now has the world's highest rate of stunting among children (43\%) and has shown little improvement over the past 15 years [1]. Childhood obesity continues to be a serious health problem across the globe [8] and has become a global epidemic both in children and in adults, and is still increasing in both industrialized and developing countries [9]. However, some studies have indicated that in developing countries there is an increase in the prevalence of overweight and obesity among children who are stunted [10-12]. More specifically, stunting has also been associated with obesity later in life [13]. The coexistence of stunting and overweight or obesity among populations in developing countries poses a major challenge to policy makers, mainly because these countries in the past have been struggling with problems of undernutrition and are now faced with the challenges that come with overweight and obesity. Therefore they may lack the infrastructure to treat and manage chronic diseases associated with obesity.

\section{Emerging trends and their effects on nutrition in sub- Saharan Africa}

Africa is gradually moving from a continent of food deficit and undernutrition to a continent with both undernutrition and overnutrition. According to Schmidhuber et al., back in the 1960s the entire developing world, except for a few countries, was suffering from substantive calorie deficits, chronic undernourishment, and in some cases outright famine [14]. They further indicate that, by the end of the 1990s, the rather homogeneous picture of low food supply and hunger of the 1960s had changed completely and the prevalence of undernourishment had fallen to levels below $10 \%$ in all regions except for sub-Saharan Africa as well as a few countries in South Asia. The more rapidly growing developing countries, in particular, are beginning to suffer from an oversupply of food energy such that hunger and obesity now often coexist in the same country or region [14].

WHO indicates that changes in diet and lifestyle resulting from industrialization, urbanization, economic development, and market globalization are having a significant impact on the nutritional status of populations [15]. Further, WHO reiterates that the processes of modernization and economic transition have led to industrialization in many countries and the development of economies that are dependent on trade in the global market. Although this has resulted in improved standards of living and greater access to services, there have been significant negative consequences in inappropriate dietary patterns and decreased physical activity, as well as a corresponding increase in related diseases [15]. The nutrition transition that has been witnessed in many parts of the world, especially in developing countries with fast-growing economies, has led to changes in dietary patterns [16-18].

Rapid urbanization and changing consumption patterns mean greater demand for agricultural products by people who often do not produce them [1]. Because of increased economic development and urbanization, populations in many developing countries are now consuming more energy, processed foods, including refined grains, and foods higher in saturated fat, sugar, and salt [19-21]. National food and nutrition policies, as well as trade policies that affect the relative price of food, may also encourage such changes. Low prices and increased income mean that people now have access to food that they could normally not afford. In most cases, these are fried, sugary, and salty foods rather than traditional whole grains and leafy vegetables. As income grows, consumers want to diversify away from cereals and other starchy foods [22] to foods that are ready to eat, highly processed, and high in salt and fat, which people find convenient. These are opposed to healthful foods, which require further preparation and processing such as cooking.

The nutrition transition is a contributing factor to increased obesity. Das [23] indicates that societal changes and the worldwide nutrition transition are driving the obesity epidemic. As incomes rise and populations become more urban, diets high in complex carbohydrates give way to diets with a higher proportion of fats, saturated fats, and sugar. At the same time, large shifts toward less physical activity are also found with the increasing use of automated transport, technology in the home, and more passive leisure pursuits. As a result, if energy intake exceeds expenditure for a long period, the surplus energy is stored as fat mass, 
and if the energy imbalance continues, the result is overweight and obesity [24].

\section{Association between stunting and overweight}

Stunting and overweight or obesity are both forms of malnutrition. Stunting represents undernutrition, whereas overweight represents overnutrition. The trend now in developing countries is the coexistence of both stunting and overweight within individuals, households, and communities. The existence of stunted children-overweight mother pairs has been reported in some studies [20,25-27], and other studies show a correlation between nutritional stunting (growth retardation attributed to undernutrition during childhood) and later obesity in developing countries $[3,13,28,29]$. A recent study in Mexico found that the prevalence of overweight with concurrent stunting among children 24 to 60 months of age was $5 \%$ in indigenous children and over $10 \%$ in nonindigenous children [30].

The prevalence of pairs of stunted children and overweight mothers is higher in Latin America than in Africa and is linked to economic development in both regions as well as to urbanization in Latin America [31]. Some developing countries that have higher numbers of overweight mothers also have higher numbers of stunted children; further, since the prevalence of overweight is higher in urban areas compared to rural areas and is now increasing in the rural areas in Africa, stunted-overweight mother pairs exist more in the urban areas [31]. This double burden brings to light factors related to intrahousehold food distribution and gestational weight gain that may lead to overweight mothers and stunted children. A study by Dieffenbach and Stein [25] indicates that the increasing prevalence of stunted children and overweight mother pairs is due to the increasing prevalence of overweight mothers and the decreasing prevalence of childhood stunting and that the underlying factors remain the same. Thus, intervention on the double burden of malnutrition does not need to change from the already existing interventions targeting overweight mothers and stunted children.

Stunting has been found to be associated with both metabolic and psychological risk factors for obesity; furthermore, nutritionally stunted children have impaired fat oxidation compared with nonstunted children from the same environment [3]. Stunted children from poor backgrounds are at risk for obesity and may gain weight over time when food supplies become sufficient to allow ad libitum consumption [3]. In urbanized developing countries with a higher gross national product (GNP), food scarcity may no longer be the driving factor behind energy intake [32]. Instead the availability of cheap, energy-dense food (including food from street vendors and fast-food restaurants) may facilitate the consumption of more calories. Therefore, families moving from rural to urban areas face the possible risk of overweight and obesity, particularly among previously stunted children.

A study of children in Brazil revealed that childhood nutritional stunting was associated with impaired fat oxidation, a factor that predicted obesity in other at-risk populations [33]. A longitudinal study, also in Brazil, indicated that girls recovering from undernutrition tend to have a high ratio of fat to protein accretion; the cause is not known [28]. In the same study, a higher increase in weight-for-height was found among the stunted than the nonstunted when higher-fat diets were consumed [28]. A study of young children in Mexico also showed that mild stunting was a risk factor for the accumulation of excess body fat [30].

Overweight and stunting have been explained differently in the studies above, especially in developing countries that are experiencing a nutrition transition. However, Africa is unique in that it is the only continent where undernutrition is still increasing in absolute numbers in spite of the progress made in poverty reduction. The increase in undernutrition is accompanied by increasing overweight and obesity. What remains unknown is the magnitude of the problem of stunting and overweight in Africa, although the problem has been discussed in many publications. In addition, there is a need to know the implications of both overweight and obesity occurring concurrently with stunting in individuals and in the same households and communities. This is a gap that needs to be filled, as it is important to both researchers and policy makers. Thus there is a need for more studies on stunting and overweight in Africa as a whole. The main focus of this systematic review is an analysis of the coexistence of, and the association between, stunting and overweight or obesity among children in sub-Saharan Africa.

\section{Methods}

A literature search of the PubMed central database was conducted for relevant articles on 5 April 2011. First we searched for review articles on the same topic to ensure that the study had not been conducted before. Two searches were performed with the search terms "stunting AND underweight AND overweight AND sub-Saharan Africa" or "stunting AND overweight AND Africa." The first search resulted in 13 articles and the second search resulted in 37 articles. When the two search results were compared, some articles were included twice. After elimination of duplicate articles, a total of 38 titles were identified that included only studies done in sub-Saharan Africa. The inclusion criteria were that the articles were published between 1990 and 2012 and contained relevant data on children 0 to 
18 years of age from sub-Saharan African countries. Nineteen studies were eliminated by year of publication and one was in Norwegian. A total of 18 studies were selected for this review. A descriptive analysis was done of the data obtained from the reviewed papers to include the prevalence of stunting and overweight, their causative factors, and the country where the study took place. The chi-square test was used to analyze the data. Our hypothesis was that stunting and overweight were independent of demographic factors, socioeconomic status, environmental factors, lifestyle, and nutritional status in the 18 studies.

\section{Results}

The results of the literature search are summarized in tables $\mathbf{1}[10,33-49]$ and 2 . Table 1 shows data on the prevalence and determinants of stunting, overweight, and stunting coexisting with overweight in sub-Saharan Africa from the 18 studies identified. Fifty-three percent of the studies were performed in South Africa, $11 \%$ in Cameroon, $11 \%$ in Nigeria, 5\% in Equatorial Guinea, and 5\% in Kenya. Three studies (16\%) involved multiple countries in Africa. The determining factors of stunting, overweight, and stunting coexisting with overweight were scored using the asterisk symbol $\left({ }^{\star}\right)$ to represent the risk factors. The number of asterisks in a column represents the number of factors in that category that influenced nutritional status. Demographic factors included age, sex, and ethnicity. Socioecnomic status indicators included income, parental education, parental occupation, and others. Environmental factors included region (urban or rural) and household size and composition. Lifestyle factors included physical activity, food choices, and dietary habits. Nutritional factors included mother's body mass index (BMI), dietary intake, and infant-feeding practices, among others. Table 2 shows the summary statistics from table 1. The results indicate that demographic, socioeconomic, and environmental factors were significant, whereas lifestyle and nutritional factors were not significant.

The prevalence of undernutrition in both preschool children and adolescents showed significant sex differences, with stunting and underweight being more prevalent in boys than in girls [10,34-37]. Adolescent girls were more likely to be overweight than boys [34, 35]; however, among preschool children, boys were more likely to be overweight than girls $(18.3 \%$ and $17.2 \%$, respectively), whereas $8 \%$ among girls and boys were both stunted and overweight [10]. The prevalence of stunting coexisting with obesity in Equatorial Guinea increased from $0.59 \%$ in 1997 to $3.59 \%$ in 2004 [38]. No statistically significant differences in the prevalence of obesity across sex and age groups were found among adolescents in a study in South Africa [34]. In a study in Equatorial Guinea between 1997 and 2004, the prevalence of overweight among children increased from $21.8 \%$ to $31.7 \%$, especially in urban areas (from $18.2 \%$ to $29.4 \%, p=.01$ ) [38], meaning that the rural areas also saw an increase in the prevalence of overweight in this country. The prevalence of overweight was also reported as high (23.8\%) among children 1 to 3 years of age in a study in South Africa [39].

\section{Demographic factors}

In the 18 studies sampled, demographic factors significantly contributed to the prevalence of overweight and stunting: $\chi^{2}(3, n=18)=18.84, p<.05$ (table 2). A study in Nigeria indicated that although boys were taller than girls, stunting was more pronounced in boys, who were $7.5 \mathrm{~cm}$ shorter than the $2006 \mathrm{WHO}$ reference, whereas girls were $3.5 \mathrm{~cm}$ shorter than the reference [35]. However, a study among adolescents in Cameroon showed that girls were more likely to be stunted than boys [40]. In Cameroon, girls might be more stunted as a result of cultural preferences whereby boys have better access to food, education, and other socioeconomic facilities than girls. In explaining overweight using demographic factors such as sex, girls tend to be more overweight than boys [34, 35, 37, 41, 42]. Regarding age as a determining factor, in a South African study, stunting was already present in children during the first year of life; this brings into focus the importance of assessment of length at birth or during the first year of life to identify stunted children for intervention [50]. Since stunting occurs as a result of chronic malnutrition, maternal nutrition before and during pregnancy becomes important if stunting in the first year of life is to be prevented. The mother's age is also a determinant of the nutritional status of the child. A study in Kenya indicated that mother's age is a positive and significant determinant of children's height and has a negative effect on the risk of stunting suggesting that children's nutritional status improves with age of the mother at the time of delivery [51].

\section{Socioeconomic factors}

In the 18 sampled studies, stunting and overweight were dependent on socioeconomic factors: $\chi^{2}(3, n=19)=8.5, p<.05$ (table 2). Out of 18 studies, 14 indicated that socioeconomic factors were associated with stunting, underweight, and overweight. Some maternal factors (occupation and education) and household factors (income and lower socioeconomic status) were associated with concurrent stunting and overweight. Household factors, such as size and composition, also have an impact, in that large household size may suggest that there is more competition for the available food. Maternal education was cited as important in improving the nutritional status of children [10, 39, 43-45, 49]. Maternal education is 
also often associated with maternal employment and higher income [10]. Having a mother who is a student increased the risk of stunting at 3 years, whereas having a working mother increased the risk of overweight [51]. A working mother in most cases would mean increased income for the household and consequently more access to food.

\section{Environmental factors}

Our study found that stunting and overweight were dependent on environmental factors: $\chi^{2}(\mathrm{df}=3, n=18)$ $=8.88, p<.05$ (table 2). Rural and urban differentials were the most common factors among the reviewed studies to affect stunting and overweight $[10,35,37$, $39,46,48,49]$. In a study in Nigeria, adolescents in rural schools were much more likely to be stunted than those in urban private schools [35]. Stunting and underweight were most severe among rural adolescents, who were 16 times more likely to be stunted and 4 times more likely to be underweight than adolescents in urban private schools [35]. Rural and urban settlements vary in poverty levels and socioeconomic status. A study in South Africa by Kruger et al. [36] reported no significant association between stunting and overweight; however, there was a tendency to gain subcutaneous fat after the age of 14 years, especially among urban girls. Living conditions, such as housing and sanitation, were also cited in some studies as important factors in the prevalence of malnutrition [36, $39,40,48]$. Sanitation and access to healthcare were reported as factors in the differences in nutritional status between urban and rural children [51]. There was an increase in overweight in the urban settlements, as reported in many studies, but the rural areas are not spared, as seen in Equatorial Guinea [38] and South Africa [37].

\section{Lifestyle}

Our study found that stunting and overweight among children were independent of lifestyle factors: $\chi^{2}(\mathrm{df}=3, n=18)=4.08$ (table 2). Although lifestyle factors, such as physical activity, are crucial in determining the nutritional status of young children, only three of the reviewed studies reported that physically inactive children were more likely to be overweight [37, $40,42]$. Two other studies indicated the importance of physical activity in proper growth and development. Smoking was also reported among some young children. A link of smoking to stunting and overweight was not reported, although studies have linked smoking among pregnant women to low birthweight $[52,53]$.

\section{Nutritional factors}

Our study found that stunting and overweight among children were independent of nutritional factors: $\chi^{2}(\mathrm{df}=3, n=18)=3.10($ table 2$)$. Considering the factors mentioned in the reviewed studies, nutritional factors were not included as an objective in many studies and that is why we find it not significant and caution must be taken in interpreting this results. In a study by Oliveria et al., the association between parental and children's dietary practices was shown to be stronger for the mother-child comparison than for the fatherchild comparison [54]. Studies have reported maternal nutritional status to be positively associated with child nutritional status [10, 55]. A study in Kenya found that maternal nutritional status was significantly associated with overweight as well as with obesity among preschool children [10]. For example: overweight mothers are more likely to have an overweight child. Therefore, the health and well-being of the mother are necessary to ensure healthy children. However, it is not always the case that overweight mothers have overweight children because some studies have reported stunting as well as underweight in households with overweight mothers $[31,56]$. Inadequate dietary intake was reported to contribute to stunting and underweight among children in many studies $[10,44,45,48]$, while formula feeding and early weaning contributed to overweight [43].

\section{Discussion}

This review investigated the prevalence and determinants of stunting and overweight among young children and adolescents. The findings were that demographic, socioeconomic, and environmental factors were significant in determining stunting and overweight in the 18 studies reviewed. Although lifestyle and maternal nutritional factors were important, we did not find them significant. This agrees with a study by Frongillo et al. [57] that indicates that socioeconomic and demographic factors are associated with worldwide stunting and wasting. However, in our study we did not look at wasting, which has been shown to be closely associated with stunting [58], but we looked at underweight, overweight, and co-occurring stunting and overweight. In our study, we found that boys had a higher prevalence of stunting than girls, whereas overweight was more prevalent in girls. Overweight among children depended more on demographic factors such as age, household composition, occupation of the mother, and the mother's BMI. Stunting occurred together with overweight among both boys and girls from 1 to 5 years of age. Stunting was more prevalent among boys than among girls. Indicators of socioeconomic status, such as mother's education, mother's occupation, and household income, were some of the determinants directly linked to stunting, whereas environmental factors, such as rural or urban setting and sanitation, influenced the rates of both stunting 
TABLE 1. Prevalence and determinants of stunting, overweight, and obesity among children and adolescents in sub-Saharan Africa ${ }^{a}$

\begin{tabular}{|c|c|c|c|c|c|c|}
\hline \multirow[b]{3}{*}{ Ref. } & \multicolumn{4}{|c|}{ Population } & \multirow[b]{3}{*}{ Country } & \multirow[b]{3}{*}{ Aim } \\
\hline & \multirow[b]{2}{*}{ Age } & \multirow[b]{2}{*}{$N$} & \multicolumn{2}{|c|}{ Sex $(\%)$} & & \\
\hline & & & $\mathrm{M}$ & $\mathrm{F}$ & & \\
\hline [10] & $3-5 \mathrm{yr}$ & 1,443 & 51.3 & 48.7 & Kenya & $\begin{array}{l}\text { To report on the prevalence of overweight and obesity } \\
\text { among preschool children in Kenya and examine the asso- } \\
\text { ciation between childhood overweight and selected mater- } \\
\text { nal and child-related factors }\end{array}$ \\
\hline [33] & $13-17.9 \mathrm{yr}$ & 5,322 & 45.1 & 54.9 & South Africa & $\begin{array}{l}\text { To investigate the nutritional status of black South African } \\
\text { teenagers according to sex and compare it with nutritional } \\
\text { profiles of teenagers in other countries }\end{array}$ \\
\hline$[34]$ & $10-19 \mathrm{yr}$ & 1,799 & 51.4 & 48.6 & Nigeria & $\begin{array}{l}\text { To assess sexual and rural-urban differences in height and } \\
\text { weight and the prevalence of stunting, underweight, and } \\
\text { overweight of schoolgoing adolescents }\end{array}$ \\
\hline$[35]$ & $13-18 \mathrm{yr}$ & 184 & 37.5 & 59.2 & South Africa & $\begin{array}{l}\text { To compare the inflammatory status of children with differ- } \\
\text { ences in nutritional status }\end{array}$ \\
\hline$[36]$ & $1-20 \mathrm{yr}$ & 3,489 & 49.4 & 50.6 & South Africa & $\begin{array}{l}\text { To investigate the prevalence and patterns of stunting and } \\
\text { overweight/obesity, and hence risk for metabolic disease, } \\
\text { in a group of children and adolescents in rural South } \\
\text { Africa }\end{array}$ \\
\hline [37] & $0-60 \mathrm{mo}$ & 522 & 54 & 46 & Equatorial Guinea & To assess trends in children's dietary habits \\
\hline$[38]$ & $12-108 \mathrm{mo}$ & 2,200 & & & South Africa & $\begin{array}{l}\text { To investigate the prevalence of overweight, obesity, and } \\
\text { stunting and evaluate determinants of these nutritional } \\
\text { disorders }\end{array}$ \\
\hline [39] & $12-16 \mathrm{yr}$ & 581 & 42.7 & 57.3 & Cameroon & $\begin{array}{l}\text { To assess adolescents' nutritional status according to SES and } \\
\text { sex using anthropometry }\end{array}$ \\
\hline$[40]$ & $10-15 \mathrm{yr}$ & 1,250 & 48.3 & 51.7 & South Africa & $\begin{array}{l}\text { To investigate the relationship between stunting and over- } \\
\text { weight among children }\end{array}$ \\
\hline [41] & $12-60 \mathrm{mo}$ & 150,482 & - & - & SSA & $\begin{array}{l}\text { To estimate levels and trends in overweight and obesity } \\
\text { among preschool children }\end{array}$ \\
\hline$[42]$ & $0-6$ mo & 46 & & & South Africa & $\begin{array}{l}\text { To determine the dietary intake of women in a poor rural } \\
\text { area during pregnancy and lactation, and to determine the } \\
\text { nutritional status and dietary intake of their infants at age } \\
6 \text { mo }\end{array}$ \\
\hline [43] & $0-12 \mathrm{mo}$ & 219 & - & - & South Africa & To evaluate feeding practices and growth patterns of infants \\
\hline
\end{tabular}




\begin{tabular}{|c|c|c|c|c|c|c|c|c|c|}
\hline \multicolumn{5}{|c|}{ Determinants } & \multicolumn{4}{|c|}{ Outcome measures } & \multirow[b]{2}{*}{$\begin{array}{c}\text { Study } \\
\text { description }\end{array}$} \\
\hline $\begin{array}{l}\text { De } \\
\text { (a) }\end{array}$ & SES (b) & $\begin{array}{l}\text { En } \\
\text { (c) }\end{array}$ & $\mathrm{L}(\mathrm{d})$ & $\begin{array}{l}\text { NS } \\
\text { (e) }\end{array}$ & HA (\%) & WA (\%) & $\mathrm{O}(\%)$ & SO (\%) & \\
\hline$*$ & * & $*$ & - & $*$ & $\begin{array}{c}35.8 \\
39.9(\mathrm{M}) \\
33.5(\mathrm{~F}) \\
(\mathrm{a}, \mathrm{b}, \mathrm{c})\end{array}$ & $\begin{array}{c}16.4 \\
18.3(\mathrm{M}) \\
14.5(\mathrm{~F}) \\
(\mathrm{a}, \mathrm{b}, \mathrm{c})\end{array}$ & $\begin{array}{c}17.8 \\
18.3(\mathrm{M}) \\
17.2(\mathrm{~F}) \\
(\mathrm{a}, \mathrm{b}, \mathrm{e})\end{array}$ & $\begin{array}{c}8.10 \\
8.9(\mathrm{M}) \\
7.2(\mathrm{~F}) \\
(\mathrm{a}, \mathrm{b})\end{array}$ & CS \\
\hline$* * *$ & * & * & - & - & $\begin{array}{c}15.7 \\
21.9(\mathrm{M}) \\
9.4(\mathrm{~F}) \\
(\mathrm{a}, \mathrm{b})\end{array}$ & $\begin{array}{c}10.5 \\
18.4(\mathrm{M}) \\
2.6(\mathrm{~F}) \\
(\mathrm{a}, \mathrm{b})\end{array}$ & $\begin{array}{c}12.6 \\
20.9(\mathrm{~F}) \\
4.2(\mathrm{M}) \\
(\mathrm{a}, \mathrm{b})\end{array}$ & - & - \\
\hline$* * * *$ & $* * *$ & * & - & - & $\begin{array}{c}15.7 \\
23.1(\mathrm{M}) \\
7.9(\mathrm{~F}) \\
(\mathrm{a}, \mathrm{b}, \mathrm{c})\end{array}$ & $\begin{array}{c}18.9 \\
23.1(\mathrm{M}) \\
14.5(\mathrm{~F}) \\
(\mathrm{b}, \mathrm{c})\end{array}$ & $\begin{array}{c}2.3 \\
1.1(\mathrm{M}) \\
3.7(\mathrm{~F}) \\
(\mathrm{a}, \mathrm{c})\end{array}$ & - & CS \\
\hline$* *$ & - & * & & * & $\begin{array}{c}18.0 \\
(\mathrm{a}, \mathrm{c}, \mathrm{e})\end{array}$ & $\overline{(c, e)}$ & - & - & CS \\
\hline ** & * & - & * & - & $\begin{array}{c}32.0 \\
(1 \mathrm{yr}) \\
3-6(5 \mathrm{yr}) \\
14-15(14-15 \\
\text { yr M }) \\
(\mathrm{a}, \mathrm{b})\end{array}$ & $\begin{array}{c}16-14.0(1-6 \text { yr }) \\
19(14 \text { yr M) } \\
(a, b)\end{array}$ & $\begin{array}{c}18.0 \\
(14 \mathrm{yr} F) \\
4(\mathrm{M}) \\
(\mathrm{a}, \mathrm{d})\end{array}$ & $\begin{array}{c}18.0 \\
(1-5 \mathrm{yr}) \\
5 \% \\
(5-9 \mathrm{yr}) \\
3 \% \\
(10-20 \mathrm{yr}) \\
\text { (a) }\end{array}$ & CS \\
\hline- & * & - & * & - & $\begin{array}{l}45.3 \\
\text { (c) }\end{array}$ & - & $\begin{array}{l}31.7 \\
(\mathrm{e})\end{array}$ & - & CS \\
\hline * & * & $* *$ & $* *$ & - & $\begin{array}{l}19.3 \\
(\mathrm{a}, \mathrm{b})\end{array}$ & $\begin{array}{c}8.8 \\
(\mathrm{a}, \mathrm{c})\end{array}$ & $\begin{array}{c}6.7 \\
(a, b, c)\end{array}$ & - & SD \\
\hline$* *$ & $* *$ & $* *$ & $* *$ & & $\begin{array}{c}12 \text { (low SES) } \\
6 \\
5 \text { (high SES) } \\
15(\mathrm{M}) \\
5(\mathrm{~F}) \\
(\mathrm{a}, \mathrm{b}, \mathrm{c})\end{array}$ & $\begin{array}{c}3 \text { (low SES) } \\
4 \\
1 \text { (high SES) } \\
5(\mathrm{M}) \\
2(\mathrm{~F}) \\
(\mathrm{a}, \mathrm{b}, \mathrm{c})\end{array}$ & $\begin{array}{c}8 \text { (low SES) } \\
11 \\
9 \text { (high SES) } \\
4(\mathrm{M}) \\
14(\mathrm{~F}) \\
(\mathrm{a}, \mathrm{d})\end{array}$ & - & CS \\
\hline$* *$ & * & $* *$ & - & - & $\begin{array}{c}\text { Rural } \\
23.7(\mathrm{~F}) \\
26.7(\mathrm{M}) \\
\text { Urban } \\
11.6(\mathrm{~F}) \\
17.1(\mathrm{M}) \\
(\mathrm{a}, \mathrm{c})\end{array}$ & - & 7.9 & 10.1 & CS \\
\hline * & * & * & - & - & - & - & $\begin{array}{c}\leq 15 \\
(\mathrm{~b}, \mathrm{c}, \mathrm{d})\end{array}$ & - & RS \\
\hline$* *$ & * & - & - & * & $\begin{array}{c}14.9(0 \mathrm{mo}) \\
34.6(6 \mathrm{mo}) \\
29.2(\mathrm{M}) \\
40.0(\mathrm{~F}) \\
(\mathrm{a}, \mathrm{b}, \mathrm{e})\end{array}$ & $\begin{array}{c}14.7(\mathrm{LBW}) \\
9.6(6 \mathrm{mo}) \\
12.5(\mathrm{M}) \\
6.7(\mathrm{~F}) \\
(\mathrm{a}, \mathrm{b}, \mathrm{e})\end{array}$ & - & - & CS \\
\hline ** & $* * *$ & - & ** & * & $\begin{array}{c}9.6(0 \mathrm{mo}) \\
(\mathrm{a}, \mathrm{b}, \mathrm{d})\end{array}$ & $\begin{array}{c}8.8(\mathrm{LBW}) \\
48.9(0 \mathrm{mo}) \\
(\mathrm{a}, \mathrm{d}, \mathrm{e})\end{array}$ & - & - & LS \\
\hline
\end{tabular}


TABLE 1. Prevalence and determinants of stunting, overweight, and obesity among children and adolescents in sub-Saharan Africa ${ }^{a}$

\begin{tabular}{|c|c|c|c|c|c|c|}
\hline \multirow[b]{3}{*}{ Ref. } & \multicolumn{4}{|c|}{ Population } & \multirow[b]{3}{*}{ Country } & \multirow[b]{3}{*}{ Aim } \\
\hline & \multirow[b]{2}{*}{ Age } & \multirow[b]{2}{*}{$N$} & \multicolumn{2}{|c|}{ Sex (\%) } & & \\
\hline & & & M & $\mathrm{F}$ & & \\
\hline [44] & $24-59 \mathrm{mo}$ & 169 & & & Cameroon & $\begin{array}{l}\text { To identify the factors associated with concurrent stunting } \\
\text { and overweight in urban preschool children }\end{array}$ \\
\hline [45] & $8-11 \mathrm{yr}$ & $\begin{array}{c}802^{b} \\
24,391^{c}\end{array}$ & & & South Africa & $\begin{array}{l}\text { To investigate the relationship between stunting and levels of } \\
\text { overweight/obesity among South African schoolchildren, } \\
\text { using two definitions of overweight and obesity, based on } \\
\text { WHO and IOTF criteria }\end{array}$ \\
\hline [46] & $15 \mathrm{yr}$ & 195 & 40 & 60 & Africa & $\begin{array}{l}\text { To examine plasminogen activator inhibitor- } 1 \text { activity, } \\
\text { fibrinogen, and thrombin-antithrombin complex in Afri- } \\
\text { can adolescents }\end{array}$ \\
\hline [47] & $12-60 \mathrm{mo}$ & 1,512 & 52.8 & 47.2 & South Africa & $\begin{array}{l}\text { To perform a secondary analysis of existing anthropometric } \\
\text { data from } 1999 \text { NFCS using the different reference stand- } \\
\text { ards from National Centre for Health Statistics percentiles }\end{array}$ \\
\hline [48] & $2-9 \mathrm{yr}$ & 330 & 55.2 & 44.8 & Africa & $\begin{array}{l}\text { To determine whether African urban children who were } \\
\text { stunted at } 2 \mathrm{yr} \text { demonstrated an altered body composition } \\
\text { by the end of childhood before entering puberty at } 9 \mathrm{yr}\end{array}$ \\
\hline [49] & $5-20 \mathrm{yr}$ & 623 & 52.3 & 47.7 & Nigeria & $\begin{array}{l}\text { To document the height and weight patterns relative to inter- } \\
\text { national standards among children and adolescents }\end{array}$ \\
\hline
\end{tabular}

CS, cross-sectional study; De, demographic; En, environmental; F, female; HA, height-for-age; L, lifestyle; LBW, low birthweight; LS, longitudinal study; M, male; NFCS, National Food Consumption Survey; NS, nutritional status; O, overweight; PC, prospective cohort study; RS, retrospective study; SD, secondary data analysis; SES, socioeconomic status; SO, stunted-overweight; SSA, sub-Saharan Africa; WA, weight-for-age

a. The determining factors of stunting, overweight, and stunting coexisting with overweight were scored using the asterisk symbol $\left({ }^{*}\right)$ to represent the risk factors. The number of asterisks in a column represents the number of factors in that category that influenced nutritional status.

and overweight. Thus, the high prevalence of stunting among male children, the role of socioeconomic factors, particularly maternal levels of education, occupation, and income, as well as maternal nutritional status, formed the highlight of the discussion in this review.

This study has shown that in developing countries, socioeconomic factors contribute significantly to the prevalence of stunting, underweight, and overweight among children and adolescents from 0 to 20 years of age $[10,35,37,40,43]$. Another study revealed that some maternal factors (lower height, age, and education) and household factors (large size and lower socioeconomic status) were associated with concurrent stunting and overweight [59]. However, male children were more prone to undernutrition than females; this agrees with a study by Kabubo-Mariara et al., which indicated that boys are more likely than girls to suffer from chronic and acute undernutrition as well as underweight [51]. The rise in the numbers of stunted and overweight children may be a result of rapid economic growth, which has resulted in a nutrition transition as well as an economic transition. Economic growth affects sections of a population differently [60]. The poor who are food insecure may suddenly be able to access foods that are cheap but lacking in nutrients, and thus overconsumption of energy-dense foods may occur, resulting in overweight and obesity. This may explain the coexistence of stunting and overweight in the same households and the same individuals.

The coexistence of stunting and overweight in the same child was found to be common in children under 5 years of age but was uncommon in older children aged 5 to 9 years and adolescents aged 10 to 20 years [37]. Children under 5 years of age have to be weaned, and therefore feeding practices and underlying hygiene and sanitation within the home may influence the nutritional status of a child. The child's nutritional status may also depend on whether the child was exclusively breastfed. According to a study in South Africa, many infants were underweight at birth but fewer were stunted; however, in the first 12 months, growth patterns changed, with infants gradually becoming more stunted and more overweight because exclusive breastfeeding for longer periods was uncommon in the study area [44]. Promotion of exclusive breastfeeding for a period of 6 months and continued breastfeeding together with complementary feeding for a period of 24 months, as outlined in the UNICEF programming guide, is therefore important in the prevention of 


\begin{tabular}{|c|c|c|c|c|c|c|c|c|c|}
\hline \multicolumn{5}{|c|}{ Determinants } & \multicolumn{4}{|c|}{ Outcome measures } & \multirow[b]{2}{*}{$\begin{array}{c}\text { Study } \\
\text { description }\end{array}$} \\
\hline $\begin{array}{l}\text { De } \\
\text { (a) }\end{array}$ & SES (b) & $\begin{array}{l}\text { En } \\
\text { (c) }\end{array}$ & $\mathrm{L}(\mathrm{d})$ & $\begin{array}{l}\text { NS } \\
\text { (e) }\end{array}$ & HA (\%) & WA (\%) & $\mathrm{O}(\%)$ & $\mathrm{SO}(\%)$ & \\
\hline$* *$ & $* *$ & $* * *$ & * & * & $\begin{array}{l}20.1 \\
(\mathrm{a}, \mathrm{e})\end{array}$ & - & $\begin{array}{l}26.0 \\
(a, c)\end{array}$ & $\begin{array}{c}27.2 \\
(\mathrm{a}, \mathrm{b}, \mathrm{c}, \mathrm{e})\end{array}$ & CS \\
\hline ** & - & * & - & - & $\begin{array}{c}2.9-40.2 \\
\text { (moderate) } \\
31.4-75 \text { (mild) } \\
(a, c)\end{array}$ & - & $\begin{array}{c}0.4-13.3^{b} \\
0.4-11.9^{c} \\
(\mathrm{a}, \mathrm{c})\end{array}$ & $\begin{array}{l}3.7^{b} \\
1.5^{c}\end{array}$ & CS \\
\hline * & - & * & - & - & $\begin{array}{l}17.5 \\
\text { (a) }\end{array}$ & - & $\begin{array}{c}53.6 \\
31.5(\mathrm{M}) \\
73.6(\mathrm{~F}) \\
(\mathrm{a}, \mathrm{c})\end{array}$ & - & CS \\
\hline * & - & * & * & * & $\begin{array}{c}20.1^{b} \\
17.1^{d} \\
14.2^{e} \\
(\mathrm{a}, \mathrm{b}, \mathrm{c}, \mathrm{e})\end{array}$ & $\begin{array}{c}6.8^{b} \\
9.7^{d} \\
9.9^{e} \\
(\mathrm{a}, \mathrm{b}, \mathrm{c}, \mathrm{e})\end{array}$ & $\begin{array}{c}20.6^{b} \\
13.0^{d} \\
16.7^{e} \\
(\mathrm{~b}, \mathrm{c}, \mathrm{e})\end{array}$ & - & SD \\
\hline * & - & - & - & * & $\begin{array}{c}16.1(2 \mathrm{yr}) \\
18(7-9 \mathrm{yr}) \\
(\mathrm{a}, \mathrm{e})\end{array}$ & - & - & - & LS \\
\hline$* * *$ & * & * & - & * & $\begin{array}{c}32.5 \\
(\mathrm{a}, \mathrm{b}, \mathrm{c}, \mathrm{e})\end{array}$ & $\begin{array}{c}37(\mathrm{M}) \\
23(\mathrm{~F}) \\
(\mathrm{a}, \mathrm{e})\end{array}$ & $\begin{array}{c}4(\mathrm{M}) \\
15.3(\mathrm{~F}) \\
(\mathrm{a}, \mathrm{e})\end{array}$ & - & LS \\
\hline
\end{tabular}

b. 2006 World Health Organization (WHO) reference standards.

c. International Obesity Task Force (IOTF) data.

d. 1977 National Center for Health Statistics (NCHS) standards.

e. 2000 Centers for Disease Control and Prevention (CDC) reference.

overweight and stunting among young children [60] , as is the need for a mother to know the importance of breastfeeding and the need for proper hygienic practices during weaning. A South African study found that a child's HIV status was a significant predictor of underweight; this is important regarding the mother's choice to breastfeed or not breastfeed, depending also on her HIV status [61].

Poor hygiene may occur as a result of a lack of clean water, poor waste disposal, contaminated water sources, and lack of knowledge of the importance of practicing proper hygiene and sanitation. A South African study also indicated that having an informal housing structure and fewer rooms in the house, poor or inadequate water and sanitation, low income, and unemployment contribute toward undernutrition [39]. In addition to poor hygienic practices, the mother's level of education was a major determinant of undernutrition in Africa*. Cultural practices may contribute to low education among women, as many cultures,

* Tlandinyane P. The difference in factors influencing childcare between mothers/caregivers of undernourished and well nourished children aged 1-4 years in Oukasie (Brits), North West Province. MEDUNSA, 2003. Unpublished Master's dissertation. particularly in Africa, still see education of girls as less important than education of boys.

With the persistent high prevalence of stunting and overweight among African children, there is need for an urgent intervention. Martorell et al. indicate that the challenge for developing countries is eliminating malnutrition and growth faltering while preventing obesity from rising [42]. Socioeconomic disparities are widening, with the poor remaining poor or worsening and the rich becoming richer. The major challenge for countries in transition is the reduction of poverty and of socioeconomic and health disparities, particularly in urban areas [32].

The coexistence of under- and overnutrition in the same households and individuals has implications for food and nutrition programming. Targeting intervention programs to both stunted and overweight individuals is a challenge, since the desired outcome is contradictory: ensuring there is no stunting, underweight, or wasting and preventing overweight. However, some important interventions for reducing the rate of undernutrition may also be beneficial in reducing the burden of obesity: promoting breastfeeding, improving the nutritional status of women of reproductive age, and reducing the prevalence of fetal 
TABLE 2. Summary of statistics on determinants of stunting, underweight, and overweight among young children and adolescents in sub-Saharan Africa

\begin{tabular}{|c|c|c|c|c|c|c|c|c|c|c|c|}
\hline \multirow[b]{2}{*}{ Determinants } & \multicolumn{2}{|c|}{ Height-for-age } & \multicolumn{2}{|c|}{ Weight-for-age } & \multicolumn{2}{|c|}{ Overweight } & \multicolumn{2}{|c|}{$\begin{array}{l}\text { Overweight } \\
\text { and stunted }\end{array}$} & \multirow[b]{2}{*}{ df } & \multirow[b]{2}{*}{$N$} & \multirow[b]{2}{*}{$\chi^{2}$} \\
\hline & Yes & No & Yes & No & Yes & No & Yes & No & & & \\
\hline $\begin{array}{l}\text { Demographic: age, } \\
\text { sex, marital status, } \\
\text { household size, etc. }\end{array}$ & 16 & 2 & 9 & 9 & 9 & 9 & 3 & 15 & 3 & 18 & $18.84^{* *}$ \\
\hline $\begin{array}{l}\text { Socioeconomic: } \\
\text { income, maternal } \\
\text { education, type } \\
\text { of school, type of } \\
\text { toilet, etc. }\end{array}$ & 10 & 8 & 7 & 11 & 5 & 13 & 2 & 16 & 3 & 18 & $8.5^{\star}$ \\
\hline $\begin{array}{l}\text { Environmental: } \\
\text { geographic loca- } \\
\text { tion, rural-urban, } \\
\text { formal-informal } \\
\text { settings, sanitation, } \\
\text { etc. }\end{array}$ & 9 & 9 & 6 & 12 & 7 & 11 & 1 & 17 & 3 & 18 & $8.88^{*}$ \\
\hline $\begin{array}{l}\text { Lifestyle: physi- } \\
\text { cal activity, care, } \\
\text { smoking, etc. }\end{array}$ & 1 & 17 & 1 & 17 & 3 & 15 & 0 & 18 & 3 & 18 & 4.08 \\
\hline $\begin{array}{l}\text { Nutritional: mater- } \\
\text { nal nutritional } \\
\text { status, dietary } \\
\text { intake, breastfeed- } \\
\text { ing, formula feed- } \\
\text { ing, etc. }\end{array}$ & 2 & 13 & 4 & 14 & 4 & 14 & 1 & 17 & 3 & 18 & 3.19 \\
\hline
\end{tabular}

${ }^{*} p<.05,{ }^{* *} p<.01$.

growth retardation and low birthweight. In addition, intervention programs for male children have to be put in place, since they are the most vulnerable, as seen in the high prevalence of stunting and underweight among boys in the reviewed studies.

\section{Conclusions}

In this review, we found demographic, socioeconomic, and environmental factors to be significant in determining stunting and overweight. Male children and those living in a rural setting are more likely to be stunted, whereas overweight among children depends more on age, household composition, occupation of the mother, and the mother's BMI. It was also noted that the mother's age at the child's birth was a positive and significant determinant of children's height, indicating that women need to delay childbearing to lower their chances of having stunted children. The coexistence of both stunting and overweight was common among children under 5 years of age. Therefore, there is a need to promote prepregnancy and pregnancy nutrition in order to prevent overweight in later childhood and adulthood. More studies are needed in other parts of sub-Saharan Africa to be able to make a conclusive report regarding the prevalence of stunting and overweight in order to come up with policy frameworks for addressing both stunting and overweight, since in this review most of the studies were from the southern region of sub-Saharan Africa.

\section{Conflicts of interest}

The authors declare that they have no conflicts of interest.

\section{Authors' contributions}

Susan Keino performed the literature research and drafted the manuscript. All authors contributed to study design, data preparation, and interpretation. All authors read, revised, and approved the manuscript.

\section{Acknowledgments}

This study was supported by funds from the Netherlands Fellowship Program through the Netherlands Organization for International Cooperation in Higher Education (Nuffic). 


\section{References}

1. Teller CH, Alva S. Reducing child malnutrition in subSaharan Africa: surveys find mixed progress. Population Reference Bureau, 2008. Available at: http://www .prb.org/Publications/Articles/2008/stuntingssa.aspx. Accessed 26 March 2014.

2. Jehn M, Brewis A. Paradoxical malnutrition in motherchild pairs: untangling the phenomenon of over- and under-nutrition in underdeveloped economies. Econ Hum Biol 2009;7:28-35.

3. Hoffman DJ. Obesity in developing countries: causes and implications. Food and Agriculture Organization, 2001. Available at: http://www.fao.org/docrep/003/ y0600m/y0600m05.htm. Accessed 9 March 2014.

4. World Health Organization. Obesity: preventing and managing the global epidemic. Working Group on Obesity. Geneva: WHO, 1998.

5. World Health Organization. Fact sheet: obesity and overweight. Geneva: WHO, 2003.

6. World Health Organization. Fact sheet: obesity and overweight. Geneva: WHO, 2006.

7. Johnson D. Africa sees growing obesity rates. Sept. 9, 2009. Available at: http://www.classesandcareers.com/ education/2009/09/09/africa-sees-growing-obesityrates/. Accessed 26 March 2014.

8. Onywera V. Childhood obesity and physical inactivity threat in Africa: strategies for a healthy future. Glob Health Promot 2010;17(2 suppl):45-6.

9. Wang Y, Lobstein T. Worldwide trends in childhood obesity. Int J Pediatr Obes 2006;1:11-25.

10. Gewa C. Childhood overweight and obesity among Kenyan pre-school children: association with maternal and early child nutritional factors. Public Health Nutr 2010;13:496-503.

11. Semproli S, Gualdi-Russo E. Childhood malnutrition and growth in a rural area of Western Kenya. Am J Phys Anthropol 2007;132:463-9.

12. Hoffman DJ, Sawaya AL, Verreschi I, Tucker KL, Roberts SB. Why are nutritionally stunted children at increased risk of obesity? Studies of metabolic rate and fat oxidation in shantytown children from São Paulo, Brazil. Am J Clin Nutr 2000;72:702-7.

13. Popkin BM, Richards MK, Monteiro CA. Stunting is associated with overweight in children of four nations that are undergoing the nutrition transition. J Nutr 1996;26:3009-16.

14. Schmidhuber J, Shetty P. Nutrition transition, obesity and noncommunicable diseases: drivers, outlook and concerns. SCN News 2005;29:13-9.

15. World Health Organization. Nutrition in transition: globalization and its impact on nutrition patterns and diet-related diseases. Geneva: WHO, 2003.

16. Obesity prevention source. Harvard School of Public Health Newsletter 2012.

17. Prentice AM. The emerging epidemic of obesity in developing countries. Int J Epidemiol 2006;35:93-9.

18. Drewnowski A, Bopkin B, The nutrition transition: new trends in the global diet. Nutr Rev 1997;55:31-43.

19. Tokunaga M, Takahashi T, Singh RB, Rupini D, Toda E, Nakamuka T, Mori H, Wilson DW. Diet, nutrients and non-communicable diseases. The Open Nutraceutical Journal 2012;5:14-159.

20. Garrett JL, Ruel MT. Stunted child-overweight mother pairs: Prevalence and association with economic development and urbanization. Food Nutr Bull 2005;26:209-21.

21. Shetty P, Schmidhuber J. Nutrition, lifestyle, obesity and chronic diseases. New York: United Nations Department of Economics and Social Affairs, 2011.

22. Haddad L. What can food policy do to redirect the diet transition? Food Nutr Bull 2005;26:238-40.

23. Das UN. Metabolic syndrome pathophysiology: the role of essential fatty acids. Ames, Iowa, USA: WileyBlackwell Publishers, 2010.

24. Bergstrom E, Hernell O. Obesity and insulin resistance in childhood and adolescence. In: Primary and Secondary Preventive Nutrition. Bendich, A, Deckelbaum, RJ, eds. Totowa, New Jersey, USA: Humana Press Inc., 2000: 165-83.

25. Dieffenbach S, Stein AD. Stunted child/overweight mother pairs represent a statistical artifact, not a distinct entity. J Nutr 2012;142:771-3.

26. Jounghee L, Houser RF, Must A, Palma de Fulladolsa $\mathrm{P}$, Bermudez OI. Socioeconomic disparities and the familial coexistence of child stunting and maternal overweight in Guatamala. Econ Hum Biol 2012;10:232-41.

27. Masibo PK, Makhoha D. Trends and determinants of undernutrition among young Kenyan children: Kenya Demographic and Health Survey; 1993, 1998, 2003 and 2008-2009. Public Health Nutr 2012; Sept 15(9):1715-27.

28. Sawaya AL, Roberts S. Stunting and future risk of obesity: principal physiological mechanisms. Cad Saude Publica 2003;19:S21-8.

29. Sawaya AL, Sesso R, Florencio TM, Fernandez M, Martins PA. Association between chronic undernutrition and hypertension. Matern Child Nutr 2005;1:155-65.

30. Fernald LC, Neufeld LM. Overweight with concurrent stunting in very young children from rural Mexico: prevalence and associated factors. Eur J Clin Nutr 2007;61:623-2.

31. Garrett JL, Ruel MT. Stunted child-overweight mother pairs: an emerging policy concern? Washington, DC: International Food Policy Research Institute, 2003.

32. Caballero B. A nutrition paradox-underweight and obesity in developing countries. N Engl J Med 2005; 352:1514-6.

33. Jinabhai CC, Reddy P, Tailor M, Monyeki D, Kamabaran N, Omardien R, Sullivan KR. Sex differences in under and over nutrition among school-going black teenagers in South Africa: an uneven nutrition trajectory. Trop Med Int Health 2007;12:944-52.

34. Omigbodun OO, Adediran KI, Akinyemi JO, Omigbodun AO, Adedokun BO, Esan O. Gender and ruralurban differences in the nutritional status of in-school adolescents in south-western Nigeria. J Biosoc Sci 2010;42:653-76.

35. Kruger SH, Pretorius R, Schutte AE. Stunting, adiposity, and low-grade inflammation in African adolescents from a township high school. Nutrition 2010;26:90-9.

36. Kimani-Murage EW, Kahn K, Pettifor JM, Tollman SM, 
Dunger DP, Gomez-Olive XF, Norris SA. The prevalence of stunting, overweight, and obesity, and metabolic disease risk in rural South African children. Biomed Central Public Health 2010;10:158-170.

37. Custodio E, Descalzo MA, Roche J, Molina L, Sanchez I, Lwanga M, Torres AM, Fernandez-Zincke E, Bernis C, Villamor E, Baylin A. The economic and nutrition transition in Equatorial Guinea coincided with a double burden of over- and under nutrition. Econ Hum Biol 2010;8:80-7.

38. Steyn NP, Labadarios D, Maunder E, Nel J, Lombard C; Directors of the National Food Consumption Survey. Secondary anthropometric data analysis of the National Food Consumption Survey in South Africa: The double burden. Nutrition 2005;21:4-13.

39. Dapi LN, Janlert U, Nouedoui C, Stenlund H, Haglin E. Socioeconomic and gender differences in adolescents' nutritional status in urban Cameroon, Africa. Nutr Res 2009;29:313-9.

40. Mukkudem-Petersen J, Kruger HS. Association between stunting and overweight among 10-15 y old children in the North West Province of South Africa: the THUSA BANA study. Int J Obes Relat Metab Disord 2004;28:842-51.

41. Martorell R, Kettel Khan L, Hughes ML, GrummerStrawn ML. Overweight and obesity in preschool children from developing countries. Int J Obes 2000;24:959-67.

42. Mostert D, Steyn NP, Temple NJ, Olwagen R. Dietary intake of pregnant women and their infants in a poor black South African community. Curationis 2005;28:12-9.

43. Mamabolo RL, Alberts M, Mbenyane GX, Steyn NP, Nthangeni NG, Delemare-Van de Waal HA, Levitt NS. Feeding practices and growth of infants from birth to 12 months in the central region of the Limpopo Province of South Africa. Nutrition 2004;20:327-33.

44. Said-Mohamed R, Allirot X, Sobgui M, Pasquet P. Determinants of overweight associated with stunting in preschool children of Yaounde, Cameroon. Ann Hum Biol 2009;36:146-61.

45. Jinabhai CC, Taylor M, Sullivan KR. Implications of the prevalence of stunting, overweight and obesity amongst South African primary school children: a possible nutritional transition? Eur J Clin Nutr 2003;57:358-65.

46. Nienaber C, Pieters M, Kruger HS, Stonehouse W, Vorster $\mathrm{HH}$. Overfatness, stunting and physical inactivity are determinants of plasminogen activator inhibitor-1 activity, fibrinogen and thrombin antithrombin complex in African adolescents Blood Coagul Fibrinolysis 2008;19:361-8.

47. Bosman L, Herselman MG, Kruger HS, Labadarios D. Secondary analysis of anthropometric data from South Africa National Food Consumption Survey, using different growth references standards. Matern Child Health J 2011;15(8):1372-80.
48. Cameron N, Wright MM, Griffiths PL, Norris SA, Pettifor JM. Stunting at 2 years in relation to body composition at 9 years in African urban children. Obes Res 2005;13:131-6.

49. Ayoola O, Ebersole K, Omatode OO, Tayo BO, Brieger WR, Salaami K, Dugas LR, Cooper RS, Luke A. Relative height and weight among children and adolescents of rural southwestern Nigeria. Ann Hum Biol 2009;36:388-99.

50. Mamabolo RL, Alberts M, Steyn NP, Delemarre-Van de Waal HA, Levitt NS. Prevalence and determinants of stunting and overweight in 3-year-old black South African children residing in the Central Region of Limpopo Province, South Africa. Public Health Nutr 2005;8:501-8.

51. Kabubo-Mariara J, Ndenge GK, Mwabu DK. Determinants of children's nutritional status in Kenya: evidence from Demographic and Health Surveys. J Afr Econ 2008;18:363-87.

52. Steyn K, De Wet T, Salojee Y, Nel H, Yach D. The influence of maternal cigarette smoking, snuff use and passive smoking on pregancy outcome: The Birth to Ten Study. Paediatr Perinat Epidemiol 2006;20:90-9.

53. Chiolero A, Bovet P, Paccand F. Association between maternal smoking and low birth weight in Switzerland: The Eden study. Swiss Med Wkly 2005;135:525-30.

54. Oliveria SA, Ellison RC, Moore LL, Gillman MW, Garrahie EJ, Singer MR. Parent-child relationships in nutrient intake: The Framingham Children's study. Am J Clin Nutr 1992;56:593-8.

55. Thuita FM, Mwadime RK, Wangombe JK. Child nutritional status and maternal factors in an urban slum in Nairobi, Kenya. East Afr Med J 2005;82:209-15.

56. Jehn M, Brewis A. Paradoxical malnutrition in motherchild pairs: untangling the phenomenon of over- and under-nutrition in underdeveloped economies. Econ Hum Biol 2009;7:28-35.

57. Frongillo EA, de Onis M, Hanson KMP. Socioeconomic and demographic factors are associated with worldwide patterns of stunting and wasting of children. J Nutr 1997;127(12):2302-9.

58. Victoria CG. The association between wasting and stunting: an international perspective. J Nutr 1992; 122:1105-10.

59. Lobstein T. Prevalence and trends in childhood obesity. In: Obesity Epidemiology: From Aetiology to Public Health ed. Growford D, Jeffery RW, Ball K, Brug J. United Kingdom: Oxford University Press, 2010:3-16.

60. UNICEF. Programming guide: infant and young child feeding. New York: UNICEF, 2011.

61. Kimani-Murage E. Exploring the paradox: double burden of malnutrition in rural South Africa. Global Health Action 2013;6:19249. http://dx.doi.org/10.3402/ gha.v6i0.19249. 